\title{
Evaluasi Rasionalitas Penggunaan Obat Antihipertensi di Instalasi Rawat Jalan RSUD Dr. Soegiri Lamongan Periode Tahun 2017
}

\author{
(Rationality Evaluation of Antihypertension Drug Use \\ in Dr. Soegiri Hospital Lamongan at 2017)
}

\author{
DIAN SA'IDAH*, HAJAR SUGIHANTORO, ABDUL HAKIM, SITI MAIMUNAH \\ Program Studi Farmasi, Fakultas Kedokteran dan Ilmu Kesehatan, Universitas Islam Negeri \\ Maulana Malik Ibrahim, Malang.
}

Diterima 29 November 2018, Disetujui 4 April 2019

\begin{abstract}
Abstrak: Hipertensi adalah penyakit tidak menular yang ditandai dengan tekanan darah yang meningkat mencapai angka $>140 / 90 \mathrm{mmHg}$. Hipertensi ini menjadi faktor risiko utama dalam menyebabkan penyakit kardiovaskular lainnya. Angka kejadian hipertensi beserta komplikasinya terus meningkat setiap tahun sehingga potensi adanya ketidakrasionalan penggunaan obat juga semakin meningkat. Tujuan penelitian ini yaitu untuk mengetahui rasionalitas penggunaan obat antihipertensi di instalasi rawat jalan RSUD Dr. Soegiri Lamongan periode tahun 2017 ditinjau dari segi tepat indikasi, tepat pasien, tepat obat, dan tepat dosis. Penelitian ini merupakan penelitian observasional yang dilakukan dengan metode deskriptif dan menggunakan data retrospektif yaitu lembar rekam medis pasien hipertensi tahun 2017. Metode pengambilan sampel yang digunakan adalah proportional stratified random sampling. Dari jumlah total 451 rekam medis pasien hipertensi, jumlah sampel yang digunakan yaitu 82 rekam medis dimana terdapat 269 lembar resep didalamnya. Data-data yang diperoleh kemudian dibandingkan dengan menggunakan literatur American Society of Hypertension (ASH) tahun 2013 dan Hypertension Clinical Guidelines tahun 2017. Hasil penelitian menunjukkan bahwa rasionalitas penggunaan obat antihipertensi di RSUD Dr. Soegiri Lamongan periode tahun 2017 yaitu tepat indikasi 100\%; tepat pasien $91,82 \%$; tepat obat $88,85 \%$; dan tepat dosis $98,14 \%$.
\end{abstract}

Kata kunci: Hipertensi, obat antihipertensi, evaluasi rasionalitas.

\begin{abstract}
Hypertension is a non-communicable disease characterized by increased blood pressure that reaches $>140 / 90 \mathrm{mmHg}$. The incidence of hypertension and its complications continues to increase every year so the potential for irrational use of drugs is also increasing. The purpose of this study was to determine the rationality of the use of antihypertensive drugs at the outpatient installation of Hospital Dr. Soegiri Lamongan in the 2017 period, which reviews the exact indication, the right patient, the right drug, and the right dosage. This study is an observational study conducted by descriptive method and uses retrospective data, namely medical record sheets of hypertensive patients in 2017. The sampling method used was proportional stratified random sampling. The study population was 451 medical records of hypertensive patients, the number of samples used was 82 medical records where there were 269 prescription sheets in it. The data obtained are then compared using the 2013 American Society of Hypertension (ASH) literature and 2017 Hypertension Clinical Guidelines. The results showed that the rationality of the use of antihypertensive drugs in Dr. Soegiri Lamongan Hospital in 2017 period is $100 \%$ accurate on indications, $91.82 \%$ right on patients, $88.85 \%$ right on drugs, and $98.14 \%$ right on dosages.
\end{abstract}

Keywords: Hypertension, antihypertensive drugs, rationality evaluation. 


\section{PENDAHULUAN}

HIPERTENSI didefinisikan sebagai penyakit tidak menular dimana keadaan ini ditandai dengan tekanan darah yang meningkat hingga angka lebih dari 140/90 $\mathrm{mmHg}$ secara persisten. Hipertensi ini umumnya disebabkan oleh adanya kombinasi dari berbagai keadaan (multifaktorial). Beberapa hasil pemeriksaan menunjukkan bahwa terjadinya hipertensi ini disebabkan adanya faktor keturunan, ketegangan jiwa, dan faktor lingkungan serta makanan (kandungan garam yang tinggi atau asupan kalium yang rendah yang dimungkinkan berperan sebagai kontributor berkembangnya hipertensi(1).

Penyakit hipertensi merupakan salah satu faktor risiko terbesar penyebab morbiditas dan mortalitas pada penyakit kardiovaskular. Penyakit hipertensi juga dapat mengakibatkan infark miokard, stroke, gagal ginjal, bahkan kematian(2). Hipertensi kerap kali disebut dengan silent killer karena pada umumnya pasien tidak mengetahui bahwa mereka menderita penyakit hipertensi sebelum memeriksakan tekanan darahnya, serta hipertensi umumnya tidak menimbulkan suatu tanda atau gejala apapun sebelum terjadi komplikasi(3).

Sekitar 1 miliar orang, yaitu sekitar seperempat dari seluruh populasi orang dewasa di dunia menyandang hipertensi, dan jumlah ini cenderung meningkat. Pada tahun 2025, diperkirakan penderita hipertensi akan meningkat mencapai angka 1,6 miliar. Menurut Riset Kesahatan Dasar tahun 2007, hipertensi menjadi penyebab utama kematian semua umur setelah stroke dan tuberkulosis dengan proporsi kematian 6,8\%(4). Data dari Riset Kesehatan Dasar tahun 2013 juga menunjukkan adanya peningkatan prevalensi hipertensi pada tahun 2007 menuju tahun 2013 yaitu dari angka 7,6\% menjadi 9,5\%(5).

Penggunaan obat yang rasional mengharuskan pasien menerima pengobatan sesuai dengan kebutuhan klinis, dalam dosis yang diperlukan tiap individu, dalam kurun waktu tertentu, dan dengan biaya yang paling rendah. Evaluasi penggunaan obat sangatlah penting dilakukan oleh apoteker dengan tujuan untuk menjamin ketepatan peresepan dan penggunaan obat, cost effectiveness, serta untuk meningkatkan kualitas

pelayanan kesehatan ditinjau dari segi tepat diagnosis, tepat indikasi, tepat pasien, tepat obat, tepat dosis, tepat informasi, tepat harga, tepat cara dan lama pemberian, serta waspada efek samping(6).
RSUD Dr. Soegiri Lamongan merupakan rumah sakit tipe B dimana sering dijadikan rumah sakit rujukan utama oleh masyarakat kabupaten Lamongan. Hasil survei awal di instalasi rawat jalan RSUD Dr. Soegiri Lamongan pada bulan Januari 2018 menunjukkan bahwa dalam periode 2017 jumlah kasus hipertensi yaitu sebanyak 751 kasus. Hipertensi beserta komplikasinya selalu menduduki urutan teratas penyakit tidak menular di RSUD Dr. Soegiri Lamongan dan jumlah kasusnya semakin meningkat tiap tahunnya. Hypertension Heart Desease (HHD) merupakan salah satu contoh komplikasi hipertensi yang jumlah kasusnya semakin meningkat dalam 3 tahun terakhir yaitu sebanyak 4599 kasus di tahun 2015, 4904 kasus di tahun 2016, dan sebanyak 5134 kasus di tahun 2017.

Semakin tinggi jumlah kasus hipertensi beserta komplikasinya maka jumlah penggunaan obat antihipertensi juga akan semakin meningkat, sehingga potensi terjadinya ketidakrasionalan penggunaan obat pun juga semakin tinggi. Berdasarkan hal inilah yang mendorong peneliti untuk mengetahui kerasionalan penggunaan obat antihipertensi yang telah diberikan sebelumnya pada pasien hipertensi di RSUD Dr. Soegiri Lamongan secara kualitatif dengan melihat dari sisi tepat indikasi, tepat pasien, tepat obat, dan tepat dosis.

\section{BAHAN DAN METODE}

BAHAN. Rekam medis pasien yang terdiagnosa utama hipertensi di instalasi rawat jalan RSUD Dr. Soegiri Lamongan pada periode tahun 2017 dengan atau tanpa penyakit penyerta.

METODE. Penelitian ini dilakukan pada bulan Maret - April tahun 2018 di RSUD Dr. Soegiri Lamongan. Jenis penelitian yang dilakukan yaitu penelitian observasional yang dilakukan dengan metode deskriptif. Pengambilan data dikumpulkan secara retrospektif yaitu menggunakan lembar rekam medis pasien hipertensi rawat jalan tahun 2017. Metode pengambilan sampel yang digunakan pada penelitian ini adalah proportional stratified random sampling. Stratified dilakukan dengan mengelompokkan sampel berdasarkan bulan pasien masuk rumah sakit. Selanjutnya sampel diambil secara random dengan proporsi yang seimbang sesuai dengan jumlahnya dalam populasi (Tabel 1). Seluruh populasi yang memenuhi kriteria penelitian yaitu rekam medis

Tabel 1. Cara perhitungan sampel proportional stratified.

\begin{tabular}{lccccccccccccc}
\hline Bulan & Jan & Feb & Mar & April & Mei & Juni & Juli & Agust & Sept & Okt & Nov & Des \\
\hline Sampel & $\frac{81 \times 82}{451}$ & $\frac{40 \times 82}{451}$ & $\frac{52 \times 82}{451}$ & $\frac{39 \times 82}{451}$ & $\frac{35 \times 82}{451}=6$ & $\frac{20 \times 82}{451}$ & $\frac{29 \times 82}{451}=5$ & $\frac{34 \times 82}{451}=6$ & $\frac{35 \times 82}{451}=6$ & $\frac{33 \times 82}{451}=6$ & $\frac{19 \times 82}{451}=4$ & $\frac{34 \times 82}{451}=6$ & \\
\hline
\end{tabular}


pasien yang terdiagnosa utama hipertensi di instalasi rawat jalan RSUD Dr. Soegiri Lamongan pada periode tahun 2017 dengan atau tanpa penyakit penyerta dan rekam medis yang lengkap dan terbaca. Evaluasi obat yang diteliti yakni memiliki batasan hanya pada obat hipertensi.

\section{HASIL DAN PEMBAHASAN}

Jumlah sampel. Jumlah sampel yang didapatkan dengan menggunakan rumus Slovin yaitu sejumlah 82 rekam medis dari jumlah total 451 rekam medis pasien hipertensi pada tahun 2017. Diketahui bahwa dalam sebagian besar rekam medis tersebut terdapat lebih dari 3 resep sehingga jumlah total resep dalam 82 rekam medis yaitu sebanyak 269 lembar resep.

Karakteristik Responden berdasarkan Jenis Kelamin. Jenis kelamin merupakan salah satu faktor risiko terjadinya hipertensi yang tidak dapat diubah. Pada penelitian ini pasien wanita lebih mendominasi dibandingkan pasien pria (Tabel 2). Mekanisme pengaruh perbedaan jenis kelamin terhadap regulasi tekanan darah belum diketahui secara detail, namun banyak penelitian yang mengaitkannya dengan sistem hormonal dalam tubuh. Hormon estrogen merupakan hormon yang turut mempengaruhi perkembangan penyakit hipertensi, dimana estrogen ini berperan dalam meningkatkan kadar High Density Lipoprotein (HDL). Kadar HDL yang tinggi merupakan faktor pelindung dari terjadinya aterosklerosis, yang mana aterosklerosis ini dapat menyebabkan terjadinya hipertensi.

Efek perlindungan estrogen dianggap sebagai penjelasan adanya imunitas wanita pada masa sebelum menopause. Pada masa menopause hormon estrogen semakin rendah kuantitasnya. Menurunnya kadar estrogen yang melindungi pembuluh darah dari kerusakan inilah yang menjadi salah satu faktor yang menyebabkan wanita rentan terkena penyakit kardiovaskular(2).

Tabel 2. Karakteristik responden berdasarkan jenis kelamin.

\begin{tabular}{lcc}
\hline \multicolumn{1}{c}{ Jenis kelamin } & $\Sigma$ Rekam Medis & Persentase (\%) \\
\hline Wanita & 44 & 53,66 \\
Pria & 38 & 46,34 \\
Jumlah & 82 & 100 \\
\hline
\end{tabular}

Tabel 3. Karakteristik responden berdasarkan usia.

\begin{tabular}{lcc}
\hline Kelompok usia & $\Sigma$ Rekam Medis & Persentase $(\%)$ \\
\hline$<45$ tahun & 3 & 3,66 \\
$45-60$ tahun & 38 & 46,34 \\
$>60$ tahun & 41 & 50 \\
Jumlah & 82 & 100 \\
\hline
\end{tabular}

Karakteristik Responden berdasarkan Usia. Usia responden dalam penelitian ini dikategorikan menjadi tiga kelompok yaitu usia dewasa $<45$ tahun, usia pertengahan (middle age) 45-60 tahun, dan lanjut usia $>60$ tahun. Jumlah rekam medis dari masingmasing kelompok usia dapat dilihat pada Tabel 3.

Hipertensi merupakan salah satu penyakit degeneratif. Semakin bertambahnya usia maka akan terjadi beberapa perubahan fisiologis dalam tubuh seperti penurunan elastisitas pembuluh darah dan perubahan struktur pembuluh darah besar yang menyebabkan lumen menjadi lebih sempit serta dinding pembuluh darah yang menjadi lebih kaku sehingga mengakibatkan tekanan darah meningkat(7).

Karakteristik Responden berdasarkan Komplikasi dan Penyakit Penyerta. Pada penelitian ini, penyakit komplikasi merupakan penyakit baru yang muncul akibat tingkat keparahan hipertensi ataupun penyakit yang merupakan faktor risiko dimana dapat memperparah kondisi hipertensi, serta penyakit yang berkaitan dengan kardiovaskular. Sedangkan penyakit penyerta yaitu penyakit yang muncul sebelum, bersamaan, ataupun sesudah pasien mengalami hipertensi, serta tidak berhubungan dengan kardiovaskular. Jumlah kasus komplikasi dan penyakit penyerta dalam penelitian ini disajikan dalam Tabel 4.

Peningkatan kadar lipid sangat erat kaitannya dengan aterosklerosis. Hal ini dikarenakan lipid merupakan faktor penting dalam terjadinya aterosklerosis. Tingginya kadar lipid dalam darah akan mempengaruhi siklus metabolisme lemak itu sendiri sehingga hal ini dapat menyebabkan dislipidemia. Terjadinya dislipidemia dapat

Tabel 4. Karakteristik responden berdasarkan komplikasi dan penyakit penyerta.

\begin{tabular}{|c|c|c|c|}
\hline Kategori & Jenis penyakit & $\Sigma$ Kasus & Persentase $(\%)$ \\
\hline \multirow{6}{*}{ Komplikasi } & Dislipidemia & 14 & 38,89 \\
\hline & CVA infark & 12 & 33,33 \\
\hline & PJK & 5 & 13,89 \\
\hline & CKD & 4 & 11,11 \\
\hline & TIA & 1 & 2,78 \\
\hline & Total $(n=36)$ & 36 & 100 \\
\hline \multirow{8}{*}{$\begin{array}{l}\text { Penyakit } \\
\text { penyerta }\end{array}$} & DM & 20 & 40 \\
\hline & $\mathrm{OA}$ & 6 & 12 \\
\hline & PNP & 4 & 8 \\
\hline & Vertigo & 3 & 6 \\
\hline & Gastritis & 3 & 6 \\
\hline & Gout & 2 & 4 \\
\hline & Dll & 12 & 24 \\
\hline & Total $(n=50)$ & 50 & 100 \\
\hline
\end{tabular}


menyebabkan aterosklerosis dalam arteri yang selanjutnya mengakibatkan tahanan perifer pembuluh darah akan meningkat sehingga tekanan darah juga akan meningkat(8).

Hipertensi jangka panjang juga dapat menyebabkan CVA (Cerebro Vaskular Accident) infark atau yang biasa dikenal dengan istilah stroke. Stroke terjadi apabila pembuluh darah arteri dalam otak mengalami hipertropi atau penebalan sehingga aliran darah ke daerah otak akan berkurang yang selanjutnya akan menyebabkan terjadinya aterosklerosis melalui efek penekanan pada sel endotel dan mengakibatkan pembentukan plak pada pembuluh darah semakin cepat. Akibatnya aliran darah ke daerah-daerah yang dilalui termasuk otak akan berkurang sehingga otak tidak akan mendapat suplai oksigen yang cukup. Kurangnya suplai oksigen inilah yang menyebabkan stroke(9).

Penyakit penyerta yang banyak diderita pasien yaitu diabetes mellitus (DM) yaitu sebanyak 20 kasus (40,0\%). Diabetes mellitus merupakan salah satu faktor risiko dalam terjadinya hipertensi. Dimana pada pasien diabetes terjadi perubahan metabolik yaitu hiperglikemia dan pengeluaran asam lemak bebas berlebih yang dapat menyebabkan penurunan availabilitas Nitrit Oxide (NO) yang diproduksi oleh endotelium pembuluh darah. NO adalah suatu molekul kimia yang dapat memodulasi otot vaskular sehingga menyebabkan vasodilatasi. Apabila terjadi gangguan fungsi endotel vaskular, maka produksi NO akan berkurang sehingga akan memicu terjadinya vasokonstriksi(10).

Gambaran Distribusi Penggunaan Obat Antihipertensi. Terapi yang digunakan pasien hipertensi di RSUD Dr. Soegiri Lamongan sangat bervariasi mulai dari monoterapi hingga kombinasi 2-5 obat antihipertensi. Variasi pengobatan ini bersifat individual berdasarkan kondisi klinis pasien karena suatu obat terkadang memberikan efek yang tidak sama pada satu individu dengan individu lainnya (Tabel 5).

Tabel 5. Variasi terapi penggunaan obat antihipertensi di instalasi rawat jalan RSUD Dr. Soegiri Lamongan tahun 2017.

\begin{tabular}{lcc}
\hline \multicolumn{1}{c}{ Variasi terapi } & $\Sigma$ Kasus & Persentase (\%) \\
\hline Monoterapi & 110 & 40,89 \\
2 Kombinasi & 117 & 43,49 \\
3 Kombinasi & 33 & 12,27 \\
4 Kombinasi & 8 & 2,97 \\
5 Kombinasi & 1 & 0,37 \\
Total & 269 & 100 \\
\hline
\end{tabular}

Berdasarkan Tabel 5 dapat diketahui bahwa variasi terapi yang paling banyak digunakan di RSUD Dr. Soegiri Lamongan periode 2017 yaitu dua kombinasi obat antihipertensi $(43,49 \%)$ dimana kombinasi ini terdiri dari golongan CCB+ACEI. Menurut Sargowo (2012), kombinasi antara golongan CCB dengan $\mathrm{ACEI} / \mathrm{ARB}$ ini telah menunjukkan efek penurunan tekanan darah yang lebih besar dibandingkan dengan penggunaan monoterapi. Kombinasi ini juga telah menunjukkan penurunan tekanan darah yang efektif pada pasien hipertensi dengan gagal ginjal tanpa mempengaruhi fungsi renal yang tersisa(11). Dalam jurnal meta analisis dinyatakan bahwa kombinasi antara ACEI/ARB dengan CCB lebih menguntungkan dibandingkan dengan kombinasi obat antihipertensi lainnya dengan menunjukkan hasil lebih rendah dalam kejadian kardiovaskular dan efek samping yang merugikan(12).

Pernyataan ini juga diperkuat oleh Syamsudin (2011) yang menyebutkan bahwa kombinasi CCB dan ACEI/ARB menunjukkan suatu efek perlindungan ginjal serta memicu pengurangan massa ventrikel kiri sehingga penggunaan kedua obat ini bermanfaat bagi pasien DM ataupun pasien penyakit ginjal(13). Tingginya penggunaan kombinasi $\mathrm{CCB}+\mathrm{ACEI}$ ini sudah tepat dilihat dari banyaknya responden dalam penelitian ini yang memiliki penyakit penyerta DM sehingga kombinasi ini menjadi pilihan utama dalam pengobatan.

Evaluasi Rasionalitas Penggunaan Obat Antihipertensi. Evaluasi rasionalitas dalam penelitian ini dihitung berdasarkan tiap lembar resep yang diterima oleh pasien, sehingga resep sebelum dan sesudahnya tidak mempengaruhi penilaian ketepatan. Berdasarkan penelitian yang telah dilakukan pada 82 rekam medis yang menjadi obyek penelitian, diketahui bahwa dalam sebagian besar rekam medis tersebut terdapat lebih dari 3 resep sehingga jumlah total resep dalam 82 rekam medis yaitu sebanyak 269 lembar resep.

Evaluasi Rasionalitas Penggunaan Obat Antihipertensi berdasarkan Tepat Indikasi. Evaluasi ketepatan indikasi merupakan suatu proses penilaian terhadap pemilihan obat yang sesuai dengan kebutuhan pasien didasarkan pada diagnosa yang ditegakkan berdasarkan alasan medis(14). Dikatakan tepat indikasi apabila pemberian obat sesuai dengan gejala yang dirasakan pasien dan diagnosis yang telah ditegakkan.

Pada penelitian ini ketepatan indikasi pada penggunaan obat antihipertensi didasarkan pada ketepatan dalam memutuskan pemberian obat antihipertensi yang sepenuhnya berdasarkan alasan medis, yaitu jika tekanan darah pasien berada 
pada angka $>140 / 90 \mathrm{mmHg}$. Penggunaan obat dikategorikan tepat indikasi apabila obat yang diresepkan sesuai dengan diagnosa adanya penyakit hipertensi. Berdasarkan penelitian yang telah dilakukan, didapatkan nilai dari ketepatan pemilihan obat antihipertensi berdasarkan tepat indikasinya yaitu mencapai $100 \%$. Hasil ini sesuai dengan penelitian oleh Salwa (2013) mengenai evaluasi penggunaan obat antihipertensi di instalasi rawat inap RS Dr. Moewardi pada tahun 2010 dengan jumlah sampel sebanyak 50 rekam medis menghasilkan ketepatan indikasi sebesar $100 \%$.

Evaluasi Rasionalitas Penggunaan Obat Antihipertensi berdasarkan Tepat Pasien. Ketepatan pasien adalah ketepatan pemilihan obat yang didasarkan dengan mempertimbangkan keadaan pasien secara individu sehingga tidak menimbulkan kontraindikasi(14). Evaluasi ketepatan pasien pada penelitian ini dilakukan dengan membandingkan kontraindikasi obat yang diberikan dengan kondisi pasien dimana dilihat dari penyakit komplikasi yang sedang diderita pasien ataupun jika ada riwayat alergi yang tertera di rekam medis.

Penelitian yang telah dilakukan pada 269 lembar resep pasien hipertensi yang disesuaikan dengan standar American Society of Hypertension (ASH) tahun 2013 menunjukkan hasil evaluasi rasionalitas penggunaan obat berdasarkan ketepatan pasien yaitu sebanyak 22 lembar resep dinyatakan tidak tepat pasien $(8,18 \%)$ dan sebanyak 247 lembar resep sisanya dinyatakan tepat pasien $(91,82 \%)$. Hasil ini berbeda dengan penelitian yang dilakukan oleh Sumawa (2015) tentang evaluasi rasionalitas berdasarkan tepat pasien dirawat inap RSUP Prof. Kandou Manado yaitu dengan jumlah sampel 39 rekam medis dan menggunakan standar JNC 7 disebutkan bahwa jumlah yang tepat pasien sebesar $100 \%$. Ketidaktepatan pasien pada penelitian ini terjadi pada kasus pasien dengan penyakit komplikasi hiperlipida dan diabetes mellitus.

Adanya ketidaktepatan pasien dalam penelitian ini disebabkan oleh obat yang diberikan tidak sesuai dengan kondisi klinis pasien, yaitu sebanyak 3 resep $(13,64 \%)$ bisoprolol diberikan pada pasien hipertensi dengan komplikasi hiperlipidemia dan 14 resep $(63,64 \%)$ pada pasien DM, serta sejumlah 5 resep $(22,73 \%)$ furosemid diberikan pada pasien hipertensi dengan penyakit penyerta DM. Pengobatan dalam resep tersebut dinilai tidak tepat obat dikarenakan bisoprolol dan furosemid tidak direkomendasikan dalam literatur ASH tahun 2013 untuk hipertensi dengan komplikasi hiperlipidemia ataupun penyakit penyerta DM.
Golongan $\beta$-Blocker memiliki efek samping dapat meningkatkan kadar trigliserida serta menurunkan kolesterol HDL(7). Golongan ini juga dapat memperburuk toleransi glukosa darah serta dapat mengganggu respons metabolik terhadap hipoglikemia sehingga penggunaan pada pasien hipertensi dengan $\mathrm{DM}$ ataupun pasien dengan risiko tinggi diabetes sebaiknya dihindari. Penggunaan furosemid dalam kasus ini juga dinilai tidak tepat karena furosemid mempunyai aktifitas diuretik yang cenderung kuat sehingga dapat mengurangi aktifitas obat antidiabetik dan akan meningkatkan potensi menurunnya fungsi ginjal jika digunakan untuk pengobatan hipertensi jangka panjang pada pasien DM yang rentan terkena penyakit ginjal kronis(15).

Evaluasi Rasionalitas Penggunaan Obat Antihipertensi berdasarkan Tepat Obat. Pemberian obat dikatakan tepat apabila jenis obat yang dipilih berdasarkan pertimbangan besarnya manfaat dan risiko dikarenakan pengobatan tersebut bersifat individual dengan memperhatikan bahwa efek obat terkadang tidak sama bagi setiap individu(16). Evaluasi ketepatan obat dalam penelitian ini dinilai berdasarkan kesesuaian pemilihan. Hasil dalam penelitian ini diketahui bahwa dari 269 resep sebanyak 30 resep $(11,14 \%)$ dinilai tidak tepat obat dan 239 resep lainnya $(88,85 \%)$ dinilai tepat obat. Hasil penelitian ini sejalan dengan penelitian yang dilakukan Yulanda (2017) di Puskesmas Sukabumi dengan jumlah sampel 96 resep dan rekam medis menghasilkan nilai ketepatan dosis sebesar 97,9\%. Ketidaktepatan obat pada penelitian ini terjadi pada kasus penggunaan obat yang tidak sesuai algoritma, yakni pasien hipertensi stage 2 mendapatkan pengobatan tunggal.

Ketidaktepatan obat dalam penelitian ini terjadi dikarenakan adanya kombinasi obat yang tidak tepat dan pemilihan variasi terapi yang tidak sesuai dengan algoritma dalam literatur yang digunakan yaitu ASH. Sebanyak 29 resep $(96,67 \%)$ kondisi pasien mengalami hipertensi stage 2 namun pengobatannya hanya menggunakan monoterapi obat antihipertensi. Hal ini dinilai tidak tepat dikarenakan dalam ASH disebutkan bahwa kombinasi obat diberikan kepada pasien hipertensi stage 1 yang gagal mencapai target tekanan darah dan pasien hipertensi stage 2 sehingga jika terdapat pasien dengan hipertensi stage 2 namun hanya mendapatkan monoterapi maka dinilai tidak tepat obat.

Adapun ketidaktepatan lainnya terjadi pada 1 resep $(3,33 \%)$ yaitu karena adanya kombinasi antara kaptopril dengan lisinopril dimana kedua obat ini merupakan satu golongan yaitu ACEI. Hal ini dinilai tidak tepat dikarenakan kombinasi obat 
antihipertensi sebaiknya dipilihkan dari golongan yang berbeda, dimulai dari dosis yang lebih rendah untuk meningkatkan keefektifan dan mengurangi potensi terjadinya efek samping(17).

Evaluasi Rasionalitas Penggunaan Obat Antihipertensi berdasarkan Tepat Dosis. Dosis merupakan salah satu aspek yang paling penting dalam menentukan efikasi obat. Apabila dosis yang diberikan terlalu rendah atau di bawah rentang terapi, maka efek terapi yang diharapkan tidak akan tercapai, begitu juga sebaliknya apabila dosis yang diberikan terlalu tinggi terutama jika obat tersebut memiliki rentang terapi sempit maka akan sangat berisiko untuk menimbulkan overdosis(6). Dalam penelitian ini dinilai tepat dosis apabila dosis yang diberikan tidak kurang dan tidak lebih dari rentang yang ditentukan dalam literatur hypertension clinical guidelines tahun 2017(18).

Hasil dalam penelitian ini diketahui bahwa dari 269 resep sebanyak 5 resep $(1,86 \%)$ dinilai tidak tepat dosis dan 234 resep lainnya $(98,14 \%)$ dinilai tepat dosis. Kasus yang terjadi pada ketidaktepatan dosis adalah pasien hanya menerima pengobatan tunggal (bisoprolol) dengan dosis yang kurang. Dosis bisoprolol yang diterima pasien $<2,5 \mathrm{mg}$ dalam sehari, yakni hanya 1 x $1 / 2$ tablet sedangkan menurut literatur Hypertension Clinical Guidelines tahun 2017 dosis minimal bisoprolol dalam sehari yaitu $2,5 \mathrm{mg}$ dan dosis maksimalnya $10 \mathrm{mg}$.

\section{SIMPULAN}

Berdasarkan penelitian yang telah dilakukan pada 82 rekam medis (269 lembar resep) pasien hipertensi di instalasi rawat jalan RSUD Dr. Soegiri Lamongan periode tahun 2017, maka kesimpulan yang dapat diambil yaitu hasil evaluasi rasionalitas penggunaan obat antihipertensi berdasarkan tepat indikasi sebesar $100 \%$. Evaluasi rasionalitas berdasarkan tepat pasien sebesar 91,82\% dengan nilai tidak tepat pasien sebesar $8,18 \%$. Ketidaktepatan pasien ini terjadi pada kasus pasien dengan penyakit komplikasi hiperlipida dan diabetes mellitus. Tepat obat sebesar $88,85 \%$ dan tidak tepat obat sebesar $11,15 \%$. Ketidaktepatan obat terjadi pada kasus penggunaan obat yang tidak sesuai algoritma, yakni pasien hipertensi stage 2 mendapatkan pengobatan tunggal. Serta tepat dosis sebesar 98,14\% dan tidak tepat dosis sebesar $1,86 \%$. Kasus yang terjadi pada ketidaktepatan dosis adalah pasien hanya menerima pengobatan tunggal (bisoprolol) dengan dosis yang kurang.

\section{DAFTAR PUSTAKA}

1. Katzung, B.G., Susan, B.M., dan Anthony, J.T. Basic and clinical pharmacology 10 th edition. China: The McGraw-Hill Companies Inc; 2014.

2. Florensia, A. Evaluasi penggunaan obat antihipertensi di instalasi rawat inap RSUD kota Tangerang dengan metode anatomical therapeutic chemical/defined daily dose pada tahun 2015. [skripsi]. Jakarta: Program Studi Farmasi; 2016.

3. Chobanian, A.V., George, L.B., Henry, R.B., William, C.C., Lee, A.G., et al. Seventh report of the joint national committee on prevention, detection, evaluation, and treatment of high blood pressure. Journal Of The American Heart Association. 2004. 42:1206-52

4. Riset Kesehatan Dasar. Jakarta: Badan Penelitian Pengembangan Kesehatan Departemen Kesehatan RI. 2007.

5. Riset Kesehatan Dasar. Jakarta: Badan Penelitian Pengembangan Kesehatan Departemen Kesehatan RI. 2013.

6. Kemenkes RI. Modul penggunaan obat rasional. Jakarta: Kementrian Kesehatan Republik Indonesia. 2011.

7. Depkes RI. Pharmaceutical care untuk penyakit hipertensi. Ditjen Bina Kefarmasian dan Alat Kesehatan Departemen Kesehatan. 2006.

8. Budiman., Rosmariana, S., Paramita P. Hubungan dislipidemia, hipertensi, dan diabetes mellitus dengan kejadian infark miokard akut. Jurnal Kesehatan Masyarakat Andalas. 2015.10(1):32-7.

9. American Heart Association. Heart International Cardiovascular Disease Statistic. 2011. [online] http:// www.american.heart.org/ diakses tanggal 11 Januari 2018.

10. Creager, M.A., Luscher, T.F., Cosentino, F., Beckman, J.A. Diabetes and vascular disease: pathophysiology, clinical consequences, and medical therapy.circulation. 2003. 108:1527-9

11. Sargowo, D. Single pill combination in antihypertensine therapy. Malang: Fakultas Kedokteran Universitas Brawijaya. 2012.

12. Chi, C., Chenhui, T., Bin, B., Shikai, Y., Marianna, K. Angiotensin system blockade combined with calcium channel blocker is superior the other combinations in cardiovascular protection with similar blood pressure reduction: a meta-analysis in 20,451 hypertensive patiens. The Journal of Clinical Hypertension. 2016. $18(8)$.

13. Syamsudin. Interaksi obat konsep dasar dan klinis. Jakarta: UI Press; 2011.

14. Sumawa, P.M.R., Adeanne C.W., dan Paulina V.Y.Y. Evaluasi kerasionalan penggunaan obat antihipertensi pada pasien hipertensi rawat inap di RSUP Prof. Dr. R. D. Kandou Manado periode Januari-Juni 2014. Jurnal Ilmiah Farmasi. 2015. 4(3) 
15. BPOM RI. Pusat Informasi Obat Nasional. 2014. [online] http://pionas.pom.go.id/ioni diakses 12 Juni 2018.

16. Kowalski, R. E. Terapi hipertensi program 8 minggu, terjemahan oleh Rani S. E. Bandung: Qanita. 2010.

17. Brunton, L., Bruce, C., Bjorn, K. Goodman and Gilman's The pharmacological basis of therapeutics 12th edition. New York: McGraw Hill Medical; 2011.
18. Anonim. Guideline for the prevention, detection, evaluation, and management of high

19. blood pressure in adults. Clinical Practice Guideline. 2017. (Tersedia di https://goo.gl/oQeHRg) 